\title{
Dinamika Masyarakat Adat Pusu Dan Pemetaan Partisifatif Penyusunan Tata Ruang Wilayah Adat
}

\author{
${ }^{1}$ Ahmad Yamin, ${ }^{2}$ Geatriana Dewi \\ Dosen Fakultas Hukum, Institut Ilmu Sosial dan Ilmu Budaya Samawa Rea \\ (IISBUD SAREA) Sumbawa Besar \\ Alamat : Jalan Olat Maras Desa Pernek Kecamatan Moyo Hulu, Kabupaten Sumbawa \\ Email : ahmadyamin69@gmail.com, geatrianadewa86@gmail.com
}

\begin{abstract}
The purpose of this research is first, to find out the dynamics of the indigenous people of Pusu in terms of their history of origin, customary structures and customary law. Second, to find out participatory mapping and spatial planning of customary territories. The research method used in this article uses a qualitative approach to produce descriptive data in the form of written or spoken words from people and observed behavior. This approach emphasizes the observed phenomena and the context of meaning that surrounds a reality, describing or describing the objective state of research (a person, institution, society and others). The solution offered in this article is that the existence of participatory mapping and spatial planning of customary territories is a strategic document that can be submitted to all levels of government to give recognition and protection to the indigenous people of Pusu in accordance with the constitutional mandate of article 18B paragraph (2) of the Basic Law. Republic of Indonesia in 1945.
\end{abstract}

Keywords : Pusu Indigenous People, Participatory Mapping, Customary Territorial Spatial Planning.

\begin{abstract}
Abstrak. Tujuan penelitian ini adalah pertama untuk mengetahui dinamika masyarakat adat Pusu dilihat dari sejarah asal usul, struktur adat dan hukum adat, kedua Untuk mengetahui pemetaan partisipatif dan penyusunan tata ruang wilayah adat. Metode penelitian yang digunakan dalam artikel ini menggunakan pendekatan pendekatan kualitatif untuk menghasilkan data deskriptif berupa kata-kata tertulis atau lisan dari orang-orang dan perilaku yang diamati. Pendekatan ini mementingkan fenomena yang teramati dan konteks makna yang melingkupi suatu realitas, menggambarkan atau melukiskan keadaan objektif penelitian (seseorang, lembaga, masyarakat dan lain-lain). Solusi yang ditawarkan dalam artikel ini bahwa dengan adanya pemetaan partisipatif dan penyusunan tata ruang wilayah adat merupakan dokumen strategis yang dapat diajukan kepada semua tingkat pemerintahan untuk memberi pengakuan dan perlindungan terhadap masyarakat adat Pusu sesuai dengan amanat konstitusi pasal 18B ayat (2) Undang-undang Dasar Negara Republik Indonesia Tahun 1945.
\end{abstract}

kata Kunci : Masyarakat Adat Pusu, Pemetaan Partisipatif, Tata Ruang Wilayah Adat. 
Jurnal Ilmu Sosial dan Pendidikan

http://ejournal.mandalanursa.org/index.php/JISIP/index

Terakreditasi Peringkat 5 (No. SK: 85/M/KPT/2020)
Vol. 5. No. 1 Januari 2021

p-ISSN: 2598-9944 e- ISSN: 2656-6753

\section{PENDAHULUAN}

Pusu sebagai masyarakat Adat pada awalnya Masyarakat adat Pusu berasal dari Jompang Batu Tulis, Korbue, Batu Pleno, Bao Rio dan Sampar Bao, sebelum akhirnya menjadi masyarakat adat Pusu. Sistem kepercayaan bersifat animisme dengan sumber mata pencaharian berburu dan meramu. Namun setelah Syek Abdullah bermukim di Pusu maka telah berganti keyakinan dari Animisme dan dinamis menjadi penganut Islam yang taat.

Untuk mengambil keputusan bapak adat dan ine adat melakukan rembuk atau musyawarah untuk mengambil sebuah keputusan yang bersifat khusus. Musyawarah dilakukan secara umum dengan melibatkan seluruh masyarakat apabila berkaitan dengan permasalahan umum.

Sebagai masyarakat hukum adat. Maka masyarakat adat Pusu mempunyai hak dan kewajiban yang sama dengan masyarakat lainnya yang ada di Indonesia yang menginginkan pengakuan dan perlindungan dengan menyajikan peta dan tata ruang wilayah adat untuk dapat diakui dan diilindungi disemua tingkat pemerintahan. Pemetaan tata ruang wilayah sebagaimana diatur dalam undangundang Nomor 26 Tahun 2007 tentang Penataan ruang, selanjutnya Undang-Undang Nomor 6 Tahun 2014 tentang Desa yang dalam pasal 1 ayat (1) menyebutkan tentang desa dan desa adat yang diberi kewenangan untuk mengatur dan mengurus rumah tangga sendiri berdasarkan kewenangan asal usul dan kewenangan lokal berskla desa. terkait dengan kepemilikan tanah milik masyarakat yang dikena obyek pembangunan diatur dalam Undang-undang Nomor 38 Tahun 2004 tentang jalan dan diatur pula dalam Peraturan Pemerintah Nomor 71 Tahun 2012 tentang Penyelenggaran Pengadaan Tanah bagi Pembangunan untuk Kepentingan Umum,

Walaupun konstitusi negara pasal 18B ayat (2) maupun pasal $28 \mathrm{i}$ ayat (3) mengatur dengan jelas tentang pemberian penghormatan dan pengakuan terhadap masyarakat adat dan undang-undang lain yang bersifat sektoral dan undang-undang lain yang mengatur tentang tata ruang wilayah yang mengikutsertakan masyarakat dalam tata ruang dan pemetaan wilayah seperti tersebut diatas. Namun pemerintah pusat maupun pemerintah daerah belum melaksanakan political will untuk memberi pengakuan terhadap masyarakat adat terutama masyarakat adat Pusu. Permasalahan yang timbul dalam tulisan ini adalah pertama bagaimana dinamika masyarakat adat Pusu dilihat dari sejarah asal usul, struktur adat/kelembagaan adat dan hukum adat. Kedua, bagaimana pemetaaan partisipatif penyusunan tata ruang wilayah adat untuk mendapat pengakuan dan perlindungan. Adapun tujuan penulisan artikel ini adalah : pertama, Untuk mengetahui dinamika masyarakat adat Pusu dilihat dari sejarah asal usul, struktur adat dan hukum adat, kedua untuk mengetahui pemetaan partisipatif dan penyusunan tata ruang wilayah adat dalam rangka memperoleh dokumen pengakuan terhadap pengakuan dan perlindungan terhadap masyarakat adat.

\section{METODE PENELITIAN}

Penelitian ini menggunakan metode penelitian kualitatif. prosedur pendekatan penelitian kualitatif untuk menghasilkan data deskriptif berupa kata-kata tertulis atau lisan dari orangorang dan perilaku yang di amati. Pendekatan ini mementingkan fenomena yang teramati dan konteks makna yang melingkupi suatu realitas, menggambarkan atau melukiskan keadaan objektif/objek penelitian (seseorang, lembaga, masyarakat dan lain-lain). Metode kualitatif merupakan prosedur meneliti yang menghasilkan data deskriptif berupa kata-kata terulis atau lisan dari orang-orang dan perilaku yang dapat diamati.

\section{Pembahasan}

Dinamika masyarakat adat Pusu dilihat dari sejarah asal usul, struktur adat dan hukum adat. a. Sejarah asal usul Masyarakat Adat Pusu 
Jurnal Ilmu Sosial dan Pendidikan

http://ejournal.mandalanursa.org/index.php/JISIP/index

Terakreditasi Peringkat 5 (No. SK: 85/M/KPT/2020)

Masyarakat adat Pusu bagian dari tau

kepal yang menutut cerita berasal dari beberapa sumber terdahulu desa Tepal bernama Kepal. Sebutan Kepal itu sebenarnya merupakan akronim dari kata Tu Kepal yang dalam bahasa Sumbawa di sebuat Tau Kepal yang kalau di Indonesiakan "benda tinggi yang dipanjat". Masyarakat yang mendiami desa Tepal itu sendiri terdiri dari empat kelompok masyarakat yang tinggal mendiami empat daerah/tempat yang letaknya tidak terlalu jauh satu sama lain yang juga dari kemepat tempat tersebut bermukim masyarakat adat Pusu. Keempat kelompok tersebut di kenal dengan sebutan Mule Kamunya. Mule Kamunya itu terdiri dari

1) Mule Kamunya Malengke yang letaknya 4 $\mathrm{km}$ dari sebelah barat desa Tepal, bukti yang masih bisa dilihat sampai sekarang ini yang berhubungan dengan kelompok tersebut ialah adanya dua batu tulis serta satu kelompok makam (pekuburan lama)

2) Mule Kamunya Melempeyang terletak di unter mantular (bukit Mantular) kurang lebih $2 \mathrm{~km}$ sebelah barat desa Tepal agak ke selatan kira-kira $3 \mathrm{~km}$ dari kelompok Mole Kamunya Malengke peningkatan dari kelompok ini ada salah satu kelompok pekuburan lama dan diantara kuburan yang ada disana terdapat satu kuburan yang memiliki sejarah khusus bagi masyarakat Tepal utamanya masyarakat adat Pusu yang sampai sekarang ini masih ada yaitu "kubur sanari Malang".

3) Mule Kamunya Padesa atau lebih dikenal dengan nama Mule Kamunya Tabajarak yang letaknya sebelah barat desa Tepal agak ke utara kira-kira $2 \mathrm{~km}$ dari kelompok Malengke peninggalan yang masih bisa disaksikan sampai sekarang ini ada dua yaitu satu kelompok makam dan satu mata air yang dianggap keramat oleh masyarakat adat Pusu.

4) Mule Kamunya Orang Mate, atau yang lebih dikenal Mule Kamunya Pola Desa letaknya agak jauh dari Komunitas Adat
Vol. 5. No. 1 Januari 2021

p-ISSN: 2598-9944 e- ISSN: 2656-6753

Pusu sekitar $10 \mathrm{~km}$ sebelah timur agak ke Utara bukti peninggalan di sana satu kelompok makam dan tiga buah batu tulis yang dikenal dengan nama "Batu Tulis Pamanto Asu".

Dalam rangka melangsungkan kehidupan kemasyarakat yang berada pada Desa Kepal (Tepal) menurut masyarakat yang tinggal di Desa Tepal dan sekitarnya termasuk masyarakat Adat Pusu bahwa Mule Kamunya Orang Mate merupakan kelompok masyarakat yang cendrung nomaden (berpindah-pindah), sehingga sering mengganggu eksisitensi kelompok lain seperti Mole Kamunya Malengke, Mule Kamunya Melempe dan Mule Kamunya Padesa.

Untuk mengantisipasi gangguan Daru Mule Kamunya Orang Mate, maka ketiga kelompok masyarakat lain melakukan kesepakatan untuk melawan gangguan tersebut, maka tersebutlah seorang pemberani yang berasal dari kelompok Mule Kamunya Melempe yang bernama "Lepu Tengke". Di bawah koordinasi dari Lepu Tengke ketiga kelompok tersebut kemudian mengadakan pertemuan yang di namakan "Pulung Rama" di suatu tempat di bawah pohon beringin yang tumbuh dekat masjid Tepal sekarang ini. Kesepakatan (Pulung) tersebut melahirkan kesepakatan yang di beri nama "Oneng Pitu" Isi kesepakatan (Pulung) yang tertuang dalam Oneng Pitu adalah sebagai berikut :

a) Otak Rama kelompok mule Kamunya Malengke yang ditunjuk sebagai Tusa Kapu

b) Otak Rama kelompok mule Kamunya Malengke ditetapkan sebagai Pasung

c) Otak rama kelompok mule Kamunya Malengke Teba Jarak ditetapkan sebagai Baeng Pulung

d) Lepit Tengke dipercaya untuk memimpin para "Jang Paleng" dalam mengahadapi Kamunya Orang Mate bila sewaktu-waktu mereka datang mengganggu.

e) Mereka sepakat untuk menyatukan diri dalam satu kelompok dan membubarkan 
Jurnal Ilmu Sosial dan Pendidikan

http://ejournal.mandalanursa.org/index.php/JISIP/index

Terakreditasi Peringkat 5 (No. SK: 85/M/KPT/2020)
Vol. 5. No. 1 Januari 2021

p-ISSN: 2598-9944 e- ISSN: 2656-6753 tiga kamunya yang ada dan membangun kampung bersama yang diberi nama "Kepal" yang langsung dikepalai oleh Tusa Kapu.

f) Meletakkan empat buah tusung. empat buah batu yang menjadi perbatasan sekaligus menjadi “Baban Galung” pintu Desa.

g) Membuat Galumang atau parit yang mengelilingi Desa

h) Nama dari tempat Tusung itu adalah :

i) Batu Pasunat (Tusung Baban Pasunat). Letaknya sebelah utara desa Tepal

j) Batu Goleng letaknya disebelah selatan desa Tepal

k) Batu Bale Ara (Tusung Bale Ara) terletak di sebelah Barat

1) Batu Basanak (Tusung Basanak) terletak di pintu masuk sebelah timur desa Tepal.

Selain bukti sejarah yang dipaparkan diatas secara spesifik sejarah masyarakat adat Pusu jika ditinjau dari asal usul dapat dideskripsikan bahwa Sekitar tahun 1.300 M sudah ada dan hadir masyarakat di wilayah adat Pusu yang saat ini menjadi masyarakat adat Pusu, hidup berkelompok yang namanya Jompong Korbue, jompong Sampar Angin, Jompong Ai Tala Bao, Jompong Kuang Palela, Jompong Bao Panua. Kehidupan masyarakat pertama disini 1300 Masehi sudah hidup manusia yang menyembah matahari atau batu Bau Mele. Kehidupan ini dilakukan oleh mereka jauh sebelumnya mengenal islam. Karena islam belakangan datang.

Kemudian masuk islam ke Pusu ini dibawah oleh namanya "Selam" sekitar pertama penyebaran islam di Sumbawa oleh kerajaan Bima tahun 1600 M. kemudian Selam ini menetap di Pusu membangun pradaban baru dengan membawa budaya baru. Yang walaupun Pusu asli tidak hilang sama sekali. Contoh rabana dulu digunakan untuk penyembahan matahari oleh masyarakat asli Pusu begitu islam masuk maka rabana digunakan untuk kegiatan keagamaan islam.

Kemudian Jompong ini disatukan oleh namanya Selam. Yang pada waktu itu berjumlah sekitar $100 \mathrm{KK}$ dengan dibuktikan saat ini kuburan tua. Setelah Selam pemimpin adat diganti oleh Syeik Abdullah yang berasal dari keturunan Selam. Dari Syeik Abdullah lahirlah anak mereka Syeik Abbas, Syeik Zainuddin yang merupakan guru dari ayahanda kepala adat masyarakat adat Pedukuhan Talonang pak Jamaluddin M. Amin.

Syeik Abdullah meninggal di Pusu, diganti dengan keturunannya untuk meneruskan tahta adat di Pusu H. Abdul Kadir. Setelah dari sini tidak ada lagi gelar Syeik di masyarakat adat Pusu. Sehingga dilanjutkan dengan sistem adat istiadat sekarang yang tidak ditentukan oleh keturunan kerena ada syarat khusus. Salah satu syaratnya adalah orang yang tidak membawa lari anak orang " Marari” maka bisa menjadi kepala adat, tidak duda" polak pit'.

Sebelum Belanda masuk ke Pusu dulu diserang oleh kerajaan dari Sulawesi, sebenarnya belanda tidak bisa masuk ke Pusu. tapi belanda sangatlah cerdik dia menguasai tempat berladang para petani sehingga petani merasa kesulitan makanan. Sehingga barulah Belanda bisa masuk ke dalam desa Pusu atas bekingan kerajaan dari Sulawesi.

Syeik H. Suaib bin Yusuf adalah ayah dari syeik Abdullah melakukan peperangan dengan Belanda, sampai dengan keturunan yang namanya Baham juga ikut berperang di jaman Belanda sehingga Belanda menjadi takut dan mundur. Di jaman kerajaan Sumbawa sampai syeik dari masyarakat adat Pusu, menjadi tempat para belajar agama orang Sumbawa dan kerajaan Sumbawa dan dunia. Dalam perkembangan selanjutnya seiring dengan perkembangan jaman masyarakat adat Pusu kemudian menjadi desa Pusu. Setelah menjadi desa, berapa kali warga Pusu mengalami perpindahan sejak sebelum merdeka sampai merdeka ada lima kali merdeka terakhir tahun 1974. Ada yang pindah ke desa Hijrah Lape Kecamatan Lape, Kecamatan Alas, Kecamatan Utan dan lainnya di daerah Kabupaten Sumbawa. Walaupun sudah pindah adat istiadat di Pusu tetap jalan sebagaimana 
Jurnal Ilmu Sosial dan Pendidikan

http://ejournal.mandalanursa.org/index.php/JISIP/index

Terakreditasi Peringkat 5 (No. SK: 85/M/KPT/2020)

saat ini yang dipimpin oleh bapak desa dan Ine desa.

Untuk menjadi kepala adat di Pusu, tidak ada istilah dengan sistem kepala adat turun temurun tapi diangkat oleh kelembagaan adat sendiri atas putusan rapat adat dan Ine desa tersebut. Sehingga saya saat ini menjadi kepala adat atas usulan dari rapat masyarakat adat dan putusan dari kelembagaan adat.

Jadi di kami masyarakat adat Pusu ini tetap keputusan tertinggi ada di kelembagaan adat. Saat ini masyarakat adat Pusu berada di dusun Pusu desa Desa Tepal Kecamatan Batulanteh Kabupaten Sumbawa. Yang terdiri dari $100 \mathrm{KK}$ dan 200 jiwa.

\section{b. Struktur Adat/ Lembaga Adat}

Untuk mengambil keputusan bapak adat dan ine adat melakukan Rapulung atau musyawarah untuk mengambil sebuah keputusan yang bersifat khusus. Musyawarah dilakukan secara umum dengan melibatkan seluruh masyarakat apabila berkaitan dengan permasalahan umum.

Struktur Kelembagaan Adat Kenegrian Pusu

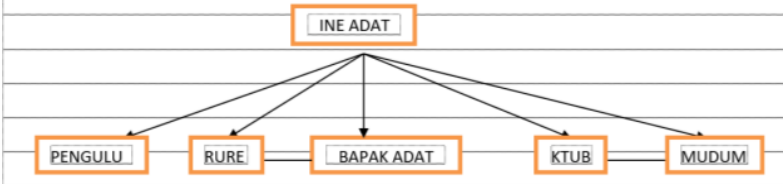

antara dunia dan akhirat. Seperti pada sttruktur adat di bawah ini:

a. Ine adat yaitu kepala adat yang mengetahui segala sesuatu yang ada di dalam lingkup wilayah adat. Segala kebijakan ditentukan oleh ine adat dengan dilakukan musyawarah dengan bawahannya. Disebut ine adat karena fokus pada internal komunitas adat atau di dalam kewilayahan adat. Ine dalam bahasa adat Pusu adalah ibu. Ibu diartikan sebagai seseorang yang aktif di rumah tangganya. Begitu juga dengan dinamakan sebagai ine adat karena dia lebih aktif dan focus dalam rumah tangga komunitas adat Pusu itu sendiri. Ine adat yang mengatur segala yang berkaitan dengan nilai-nilai adat Pusu.
Vol. 5. No. 1 Januari 2021

p-ISSN: 2598-9944 e- ISSN: 2656-6753

b. engulu yaitu pendamping ine adat atau sebagai penganti pertama Ine adat ketika berhalangan. Pengulu memegang peran penting yaitu mengingatkan Ine adat apabila keluar dari jalur hukum adat atau kebiasan dalam tradisi-tradisi di komunitas adat Pusu.

c. Rure yaitu sesorang yang mengetahui segala bentuk administrasi di komunitas adat Kenegrian Pusu. Rure juga berfungsi sebagai notulen atau sekretaris adat di Kenegrian Pusu. Selain itu, rure juga yang yang memastikan waktu setiap pelaksanaan pranata-pranata adat.

d. Ktub yaitu seseorang yang ditugaskan menyampaikan berita atau pengumuman dalam setiap keputusan adat atau menyampaikan hal-hal yang penting kepada masyarakat komunitas adat Kenegrian Pusu. Selain sebagai seseorang yang melakukan pengumuman, rure juga bertugas sebagai juru bicara dari komunitas adat Kenegrian Pusu.

e. Mudum yaitu seseorang yang melakukan pemanggilan dan yang bertugas menyembunyikan bel atau lonceng dan gong dalam setiap kegiatan pranata-pranata adat dan setiap kegiatan syukuran di komunitas adat Kenegrian Pusu.

f. Bapak adat yaitu pelaksana di lapangan atau yang mengimplementasikan dari setiap hukum adat dan nilai-nilai adat serta tradisitradisi di komunitas adat Kenegrian Pusu. Bapak adat juga yang berfungsi dan bertugas melakukan sertiap kegiatan di luar komunitas. Bapak dalam bahasa Kenegrian Pusu yaitu seorang laki-laki yang ditafsirkan sebagai sesorang yang kebanyakan aktif di luar rumah. Begitu juga bapak adat yaitu orang yang kebanyakan aktif melakukan dan menyelenggarakan hubungan dan kegiatan di luar komunitas. Namun demikian Bapak Adat juga yang memastikan nilai-nilai adat dilaksanakan di komunitas adat Kenegrian Pusu. Bapak adat memegang peran yang sangat penting dan 
sangat berat. Karena tugas dan fungsi yang sangat berat sehingga harus ada pembantupembantu di bawahnya yaitu:

g. Mandor Sei yaitu seorang yang selalu mendampingi bapak adat. Mandor Sei bertugas menganti posisi bapak adat bila berhalangan.

h. Mandor Due yaitu sesorang yang melakukan pengumuman kesetiap masyarakat komunitas adat Kenegrian Pusu sesuai dengan keputusan bapak adat. Selain sebagai seseorang yang melakukan pengumuman mandor due juga yang bertugas menjaga atau sebagai hansip/security yang bertugas mengelilingi pemukiman komunitas adat Kenegrian Pusu.

i. Petih yaitu seorang yang menjaga dan melindungi bapak adat dalam setiap gangguan. Petih juga yang bertugas menyampaikan amanat bapak adat ke luar wilayah.

j. Tamang yaitu seorang atau beberapa orang yang ditunjuk oleh bapak adat yang dipercaya mengurus orang hamil, melahirkan, sakit atau dalam bahasa modern sebagai bidan atau perawat masyarakat "khususnya perempuan" dengan cara-cara tradisional.

k. Nti adat yaitu orang mengawasi dan melindungi komunitas dari gangguan ghoib dan memegang kendali pemukiman dari setiap yang berkaitan dengan mahluk jin yang menganggu kondisi masyarakat.

1. Sandro kampung yaitu orang yang memiliki pengetahuan dan kelebihan dalam mengobati orang yang sakit dan yang mengetahui ramuan-ramuan tradisinal atau Lolo Kayu yang menjadi obat-obatan.

\section{Sumber Daya Alam}

1) Setiap warga tidak boleh berladang dan menebang pohon di hutan adat. Kecuali yang bersifat non kayu.

2) dalam berladang harus dilakukan berindahpindah tempat artinya tidak boleh berladang secara berturut-turut ditempat yang sama.
3) Tidak boleh menebang pohon di sumber mata air.

4) Tidak boleh menggarap dan menebang pohon di tue (hutan) keramat.

5) dalam pengelolaan hutan garapan sebagai kebun kopi harus disertai dengan penanaman pohon air (rope).

6) tidak boleh menebang pohon besar dalam mengelolala hutan garapan sebelum tumbuh dengan besar pohon air (rope).

Mekanisme Pengambilan Keputusan adat.

Untuk mengambil keputusan Bapak Adat dan Ine Adat melakukan rembukkan atau musyawarah adat untuk mengambil sebuah keputusan yang bersifat khusus. Musyawarah dilakukan secara umum dengan melibatkan seluruh masyarakat adat /masyarakat biasa apabila berkaitan dengan permasalahan umum. Pelaksanaan aturan dalam kenegrian Pusu Ine adat legislatif yang menyusun perangkat peraturan yang berlaku untuk semua masyarakat adat kenegrian Pusu, sementara Bapak Adat adalah Eksekutiif yang menjalankan kebijakan perangkat aturan yang ditetapkan oleh Ine Adat. Terdapat juga lembaga yudikatif yang meliputi seluruh perangkat yang ada dalam struktur adat untuk memutuskan suatu perkara dalam hal pelanggaran adat yang nantinya merupakan keputusan bersama sebagai keputusan adat. Warga adat yang melanggar norma atau kaidah adat setelah diputuskan dalam musyarawarah adat maka akan menerima sanksi adat baik sanksi badan maupun sanksi lain dalam bentuk diasingkan atau dikeluarkan sebagai anggota masyarakat adat kenegrian Pusu. Hukum adat adalah seperangkat norma yang dipatuhi dalam lingkungan masyarakat hukum adat yang dijalankan oleh otoritas (pemegang wewenang) lembaga dan bagi pelanggar akan dikenakan sanksi.

\section{Pemetaan partisipatif dan penyusunan tata ruang wilayah adat. Pemetaan Wilayah adat}

Pemetaan wilayah adat merupakan suatu usaha terencana dan dilakukan secara sistimatis 
Jurnal Ilmu Sosial dan Pendidikan

http://ejournal.mandalanursa.org/index.php/JISIP/index

Terakreditasi Peringkat 5 (No. SK: 85/M/KPT/2020)
Vol. 5. No. 1 Januari 2021

p-ISSN: 2598-9944 e- ISSN: 2656-6753 untuk mendukung usaha pengakuan dan perlindungan hak-hak masyarakat adat atas ruang hidup dan sumberdaya alam yang menjadi aset-aset penghidupannya. Oleh karena itu, maka kerja pemetaan wilayah adat milik masyarakat adat harus dilakukan secara benar dan berdayaguna dengan melibatkan masyarakat adat secara penuh dan aktif. Dalam hal ini, mandat sosial dari masyarakat adat harus ada, karena masyarakat adat adalah pemilik peta. Agar supaya hasil pemetaan wilayah adat memiliki kekuatan politik, legal secara hukum, diterima kebenarannya, dan dapat berkontribusi terhadap pembangunan, maka dukungan dan keterlibatan pemerintah sangat dibutuhkan.

Untuk menjadi fasilitor pemetaan wilayah adat milik masyarakat adat, tidak ada metode dan strategi baku. Berdasarkan kajian dan pertimbangan situasi wilayah, kondisi masyarakat dan tujuan program, boleh saja membuat rancangan baru/menyempurnakan rancangan yang telah ada untuk menciptakan metode yang cocok dan strategi yang bisa dijalankan. Yang tidak boleh dirubah adalah prinsip Pemetaan Partisipatif (PP) dan nilainilai yang menjiwai pemetaan wilayah adat secara partisipatif. Berdasarkan pertimbangan situasi wilayah Masyarakat Adat Pusu (geografis, ekologi, politik, dan lain-lain) dan kondisi kehidupan masyarakat adat Pusu (sejarah,sosial, budaya, ekonomi dan politik), maka seorang Fasilitator Pemetaan Partispatif sebaiknya tidak memfasilitasi sekaligus kedua aspek tersebut.

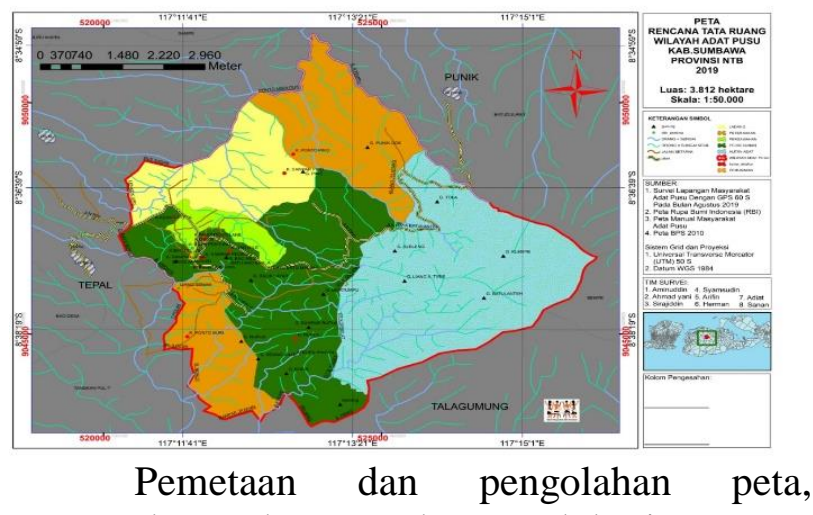
masyarakat adat mendapat edukasi tentang pemetaan wilayah dan perencanaan tata ruang wilayah pada level masyarakat adat. Dengan Pemetaan dan perencanaan tata ruang wilayah adat, masayrakat adat memahami eksistensinya sebagai masyarakat adat yang sangat mengggantungkan kehidupan dengan tanah secara berkesinambungan dari generasi ke generasi. Disamping itu keberadaan tata ruang wilayah adat merupakan posisi tawar dan nilai tawar dari masyarakat adat dengan pemerintah pusat, pemerintah Provinsi dan pemerintah kabupaten untuk mendapatkan legalitas dalam bentuk produk hukum pada tingkat daerah baik dalam bentuk Peraturan Daerah maupun Surat Keputusan Bupati.

Manfaat secara teknis pemetaan dan pengelolaan peta, masyarakat adat semakin mendapat pemahaman dan pelajaran lapangan tentang proses pemetaan partisipatif serta ikut serta dalam proses perencanaan wilayah, berdasarkan masukan saran dalam musyarawarah di tingkat masyarakat adat. Hal lainnya adalah pengenalan proses dari awal sampai akhir dari proses pemetaan partisipatif. Disamping itu juga ada interaksi sosial yang terjadi antara masyarakat adat yang satu dengan masyarakat adat lain dalam membangun kesepakatan mengenai batas wilayah, serta membangun kesadaran baru dari masyarakat adat dalam hal klaim wilayah melalui proses pemetaan.

a. Rencana Tata ruang wilayah adat Pusu

Menurut Pasal 1 butir 2 Undang-undang Nomor 26 Tahun 2007 tentang Penataan ruang (UUPR), dikatakan bahwa tata ruang adalah wujud struktur ruang dan pola ruang. Supaya Tata Ruang tersebut dapat dilaksanakan dengan baik maka diperlukan cara untuk dilakukan Penataan Ruang. Hal ini diperjelas dalam Pasal 1 butir 5 UUPR bahwa penataan ruang adalah suatu sistem proses perencanaan tata ruang, pemanfaatan ruang dan pengendalian ruang.

Adapun tujuan penataan ruang berdasarkan Pasal 3 UUPR yang menyatakan bahwa:

"Penyelenggaraan penataan ruang bertujuan untuk mewujudkan ruang wilayah nasional 
Jurnal Ilmu Sosial dan Pendidikan

http://ejournal.mandalanursa.org/index.php/JISIP/index

Terakreditasi Peringkat 5 (No. SK: 85/M/KPT/2020)

yang aman, nyaman, produktif, dan berkelanjutan berlandaskan Wawasan

Nusantara dan Ketahanan Nasional dengan:

a) Terwujudnya keharmonisan antara lingkungan alam dan lingkungan buatan;

b) Terwujudnya keterpaduan dalam penggunaan sumber daya alam dan sumber daya buatan dengan memperhatikan sumber daya manusia; dan

c) Terwujudnya perlindungan fungsi ruang dan pencegahan dampak negatif terhadap lingkungan akibat pemanfaatan ruang.

Saat ini, suatu rencana tidak dapat dihilangkan dalam hukum administrasi, dimana rencana dapat dijumpai dalam berbagai bidang kegiatan pemerintah, misalnya dalam hal pengaturan mengenai tata ruang. Menurut Saul M. Katz, terdapat alasan atau dasar dari diadakannya suatu perencanaan yaitu diantaranya:

a) Dengan adanya suatu perencanaan diharapkan terdapat suatu pengarahan kegiatan, adanya pedoman bagi pelaksanaan kegiatan-kegiatan yang ditujukan kepada pencapaian suatu perkiraan.

b) Dengan perencanaan diharapkan agar terdapat suatu perkiraan terhadap hal-hal dalam masa pelaksanaan yang akan dilalui. Perkiraan tidak hanya dilakukan mengenai potensi-potensi dan prospek-prospek perkembangan, tetapi juga mengenai hambatan-hambatan dan resiko-resiko yang mungkin dihadapi, dengan perencanaan mengusahakan agar ketidak pastian dapat diatasi sedikit mungkin.

c) Dengan perencanaan dilakukan penyusunan skala prioritas dengan memilih urutan yang dilihat dari segi pentingnya suatu tujuan, sasaran maupun kegiatan usahanya.

d) Perencanaan memberikan kesempatan untuk memilih berbagai alternatif tentang cara atau kesempatan untuk memilih kombinai terbaik.
Vol. 5. No. 1 Januari 2021

p-ISSN: 2598-9944 e- ISSN: 2656-6753

e) Dengan adanya rencana, maka akan ada suatu alat pengukur atau standar untuk mengadakan pengawasan atau evaluasi.

Masyarakat asli di suatu daerah memiliki cara pandang, wawasan dan konsep terkait lingkungan mereka, cara pandang serta konsep itulah yang dapat kita artikan sebagai bagian dari kearifan lokal. Kearifan lokal memiliki cakupan yang lebih luas daripada sekedar pengetahuan tradisional. Kearifan lokal merupakan perwujudan implementasi artikulasi dan pengejawantahan serta bentuk pengetahuan tradisional yang dipahami oleh manusia atau masyarakat yang berinteraksi dengan alam sekitarnya, sehingga kearifan lokal merupakan pengetahuan kebudayaan yang dimiliki kelompok masyarakat tertentu mencakup model-model pengelolaan sumber daya alam secara lestari termasuk bagaimana menjaga hubungan dengan alam melalui pemanfaatan yang bijaksana dan bertanggung jawab. Dengan demikian kearifan lokal adalah suatu sistem yang mengintegrasikan pengetahuan, budaya dan kelembagaan serta praktik mengelola sumberdaya alam.

Konsep tata ruang, sejatinya sudah sejak lama dikenal oleh masyarakat Indonesia, bahkan sebelum ledakan penduduk terjadi seperti saat ini. Adanya ruang yang dikeramatkan, hutan yang dikeramatkan, lahan yang tidak boleh untuk mendirikan rumah, kawasan pemukiman yang berkelompok, kawasan untuk kuburan, kawasan untuk jalan, kawasan untuk pemujaan, kawasan untuk pertanian, merupakan bentuk tata ruang lokal yang dikenal oleh masyarakat Indonesia pada umumnya. Akan tetapi, oleh masyarakat "modern" tata ruang yang telah dibangun oleh nenek moyang ini dianggap sebagai sebuah konsep yang "kosong, tidak berdasar" dan "tanpa makna", karena tidak mampu dijelaskan secara rasional dan ilmiah. Akibatnya, penggunaan ruang dilakukan sesuai dengan keinginan tanpa memperhatikan kapasitas ruang dan daya dukung lingkungan. Dapat dipastikan, tata ruang menjadi rusak dan tanpa bentuk yang 
Jurnal Ilmu Sosial dan Pendidikan

http://ejournal.mandalanursa.org/index.php/JISIP/index

Terakreditasi Peringkat 5 (No. SK: 85/M/KPT/2020)
Vol. 5. No. 1 Januari 2021

p-ISSN: 2598-9944 e- ISSN: 2656-6753 pasti. kearifan lokal suatu daerah sangat memengaruhi kedudukannya dalam penataan ruang sebab berkaitan erat dengan hukum adat dan masyarakat dimana tempat itu berada.

Pada umumnya, konsep dan pemaknaan masyarakat hukum adat termasuk hak-hak tradisionalnya cukup jelas terlindungi dalam berbagai peraturan hukum, tetapi dalamimplementasinya tidak mudah diterapkan. Kecenderungan muatan materi demikian jelas tidak dapat memberikan kepastian hukum malah sebaliknya dapat menegasikan masyarakat hukum adat. Dengan adanya empat syarat komulatif yaitu, masyarakat hukum adat sebagai subyek hak jika masih ada, berkesesuaian dengan kondisi masyarakat tidak bertentangan dengan NKRI dan diatur oleh undang-undang. Dukungan masyarakat internasional melalui kebijakan meratifikasi Konvensi internasional ke dalam sistem hukum nasionalnya sangat diperlukan. Sehingga negara melalui undang- undang diwajibkan mengakomodir perlindungan hak-hak masyarakat adat.

Hal ini bukan saja terjadi karena ketidakpastian hukum peraturan perundangundangan di tingkat pusat, akibat pengakuan dan penghormatan terhadap MHA, melainkan karena dalam tingkat UU Sektoral lainnya yang menegasikan MHA. Meskipun demikian, hadirnya nilai-nilai demokrasi dalam masyarakat lokal memerlukan adanya rule of law di tingkat daerah. Jika lahirnya perda-perda adat sebagai pengganti kekosongan hukum ditingkat pusat menjadi sangat wajar jika menimbulkan masalah baru.

Senada dengan itu, hasil kajian Gregory Acciaolli dengan judul From Acknowledgment to Oprationalization of Indegeneous Sovereignty, mengajukan beberapa kesimpulan bahwa klaim kedaulatan masyarakat hukum adat tidak diterapkan, meskipun instrumen hukum nasional dan internasional telah mendukungnya. (1) Ketidakjelasan istilah kedaulatan bagi masyarakat adat untuk dapat diimplementasikan dalam kaitannya dengan hak-hak adat terhadap wilayah adat, sebagaimana halnya perbedaan penggunaan konsep pemukiman kembali pada masyarakat adat yang tinggal di wilayah komunitas adatnya. (2) Faktor eksternal terkait gerakan kemandirian masyarakat itu sendiri, yakni terkait dengan kelangsungan pengawasan tanah agraria.

Pengakuan pemerintah terhadap prinsipprinsip adat dengan penolakan terhadap sebagain khusus klaim adat, bukan sekedar cerita semata. Dalam beberapa hal, reformasi otonomi daerah pemerintah pusat yang turun ke pemerintah provinsi dan tingkat kabupaten, berakibat timbulnya tingkat penekanan pendapatan daerah yang kebanyakanditentang karena secara langsung bersinggungan dengan hak-hak masyarakat adat. Kemunduran studi hukum adat dan masyarakat hukum adat, antara lain oleh karena anggapan bahwa hukum adat dan masyarakat hokum adat ini inkompatibel dengan semangat kebangsaan dan bahwa masalah hukum adat ini dipandang sebagai bagian dari masalah SARA (suku, agama,ras dan antargolongan) yang merupakan ancaman bagi ketahanan nasional. Walaupun eksistensi dan hak-hak masyarakat hukum adat secara formal diakui dalam UUD 1945, terutama terkait dengan hak atas tanah ulayat, namun dalam kenyataannya hak-hak tersebut secara berkelanjutan telah dilanggar baik oleh Pemerintah maupun pihak non-Pemerintah. Pelanggaran- pelanggaran ini meliputi pelanggaran terhadap hak ekonomi, sosial dan budaya yang berujung pada pelanggaran hak sipil dan politik. Pelanggaran hak-hak secara berkelanjutan tersebut merupakan salah satu faktor terjadinya konflik horizontal dan atau konflik vertikal yang tidak jarang memakan korban jiwa dan harta

Kepastian hukum budaya dalam masyarakat sangat jelas berbeda dengan pemerintahan desa. Bab 1 pasal 1 Undandundang Nomor 6 Tahun 2014 tentang Desa menyebutkan Desa adalah Desa dan desa adat atau dengan nama lain, adalah kesatuan 
Jurnal Ilmu Sosial dan Pendidikan

http://ejournal.mandalanursa.org/index.php/JISIP/index

Terakreditasi Peringkat 5 (No. SK: 85/M/KPT/2020)

masyarakat hukum yang memiliki batas-batas wilayah yang berwenang untuk mengatur dan mengurus kepentingan masyarakat setempat, berdasarkan asal-usul dan adat istiadat setempat yang diakui dan dihormati dalam sistem Pemerintahan Negara Kesatuan Republik Indonesia. Berbagai persoalan yang melibatkan adat terkadang melibatkan pihak lain,sehingga pertikaian tak luput untuk diidentifikasi. Karena itu, proses dan mekanisme pemberian ganti rugi digunakan untuk mencegah timbulnya konflik. Sengketa dalam kepemilikan masyarakat hukum adat dapat meniimbulkan persoalan. Dalam mengantisipasinya, beberapa peraturan perundangan mengatur dan menjelaskan mengenai pemberian ganti rugi atau peralihan hak tersebut. Hak ganti rugi dalam proses peralihan hak terkait dengan hal kepentingan umum (public interest). Pembangunan dan kepentingan umum. telah diatur dalam PP No. 71 Tahun 2012. Dalam Pasal 21 Ayat (1) PP No 71 Tahun 2012 tentang Penyelenggaran Pengadaan Tanah bagi Pembangunan untuk Kepentingan Umum, disebutkan bahwa pemilik tanah bekas milik adat sebagaimana dimaksud dalam Pasal 17 Ayat (2) huruf (d) merupakan pemegang hak milik atas tanah bekas tanah milik adat sebagaimana diatur dalam ketentuan konversi menurut ketentuan peraturan perundang-undangan di bidang Agraria.

Kepemilikan tanah bekas milik adat sebagaimana Ayat (1) dibuktikan dengan akta pemindahan hak yang dibuat di bawah tangan yang dibubuhi tanda kesaksian oleh kepala adat, lurah, kepala desa atau nama lain yang dibuat sebelum berlakunya Peraturan Pemerintah Nomor 10 Tahun 1961 tentang Pendaftaran Tanah dengan disertai alas hak yang dialihkan. Pasal 58 Ayat (3) UU No 38 Tahun 2004 tentang Jalan diatur ketentuannya. Bahwa penggantian dapat diberikan kepada pemegang hak atas tanah, atau pemakai tanah negara, atau masyarakat ulayat hukum adat, yang tanahnya diperlukan untuk pembangunan jalan, berhak mendapat ganti kerugian.
Vol. 5. No. 1 Januari 2021

p-ISSN: 2598-9944 e- ISSN: 2656-6753

Masyarakat Adat Pusu sebagaimana disebut pada bagian pendahuluan buku ini adalah mempunyai asal usul, sejarah, struktur adat dan wilayah serta hukum adat. Berdasarkan hasil pemetaan dan kegiatan pada workshop profil terdapat 6 peta perencanaan tata ruang yaitu :

$>$ Tata Ruang untuk Persawahan

> Tata Ruang Untuk Peternakan

$>$ Tata Ruang untuk Hutan Adat

$>$ Tata Ruang untuk Perladangan

\section{KESIMPULAN}

1. Masyarakat adat Pusu bagian dari tau kepal yang menurut cerita berasal dari beberapa sumber terdahulu desa Tepal bernama Kepal. Sebutan Kepal itu sebenarnya merupakan akronim dari kata Tu Kepal yang dalam bahasa Sumbawa di sebuat Tau Kepal yang kalau di Indonesiakan "benda tinggi yang dipeluk". Masyarakat yang mendiami desa Tepal itu sendiri terdiri dari empat kelompok masyarakat yang tinggal mendiami empat daerah/tempat yang letaknya tidak terlalu jauh satu sama lain yang juga dari kemepat termpat tersebut bermukim masyarakat adat Pusu. Setelah masuknya islam masyarakat adat pusu membentuk struktur adat dan hukum adat untuk menjadi keselarasan sosial dan budaya serta membuat tatanan hidup yang mengatur prilaku masyarakat dalam struktur kelembagaan dan hukum adat.

2. Dalam rangka untuk mendapatkan pengakuan dan perlindungan dari pemerintah pada semua tingkat pemerintahan baik Pemerintah Pusat, Pemerintah Provinsi NTB dan Pemerintah Kabupaten Sumbawa mayarakat Pusu melakukan pemetaan partisipatif wilayah adat dan penyusunan Tata Ruang wilayah adat untuk memperoleh dokumen spasial, sosial, sektoral dan kewilayahan dalam rangka melakukan peruntukan tata guna tanah dan lingkungan hidup sekitarnya. 


\section{BIOGRAFI PENULIS}

1. Ahmad Yamin adalah Dosen Fakultas hukum Institut Ilmu Sosial dan iImu Budaya Samawa Rea Sumbawa Besar pada bidang konsentrasi hukum Tata Negara. Lulus S1 tahun 1993 pada Program Studi Ilmu Hukum Fakultas Hukum Univ. Mataram. Lulus S2 Tahun 2005 pada program Magister Ilmu Hukum Fakultas Hukum Univ. Mataram dan Lulus S3 Tahun 2019 pada Program Doktor Ilmu hukum fakultas hukum Universitas Mataram.

2. Geatriana Dewi adalah Dosen Fakultas hukum Institut Ilmu Sosial dan iImu Budaya Samawa Rea Sumbawa Besar pada bidang konsentrasi hukum Pidana. Lulus S1 tahun 2008 pada Program Studi Ilmu Hukum Fakultas Hukum Univ. Mataram. Lulus S2 Tahun 2011 pada program Magister Ilmu Hukum Fakultas Hukum Univ. Mataram.

\section{DAFTAR PUSTAKA}

Asep Warlan Yusuf, Pranata Pembangunan, (Bandung: Universitas Parahyangan, 1997)

Moleong Lexy.L.J. Metodologi Penelitian Kualitatif, (Bandung Rosdakarya 1996),

Suhartini, "Kearifan Lokal dan Konservasi Keanekaragaman Hayati”, (Yogyakarta, UGM, 2009).

Akmal, "Laporan hasil penelitian Eksistensi, Hak dan Dasar Hukum Masyarakat Hukum Adat Provinsi Sumatra Barat., dalam Mengurai Kompleksitas Hak Asasi Manusia (Kajian MultiPerspektif)", (Yogyakarta, Pusham UII. 2007)

Masalah dan Solusinya (Jakarta.'The Habibie Center dan Penerbit Ombak". 2010) 